\title{
PERAN MEDIA SOSIAL DI INTERNET PADA PENERAPAN PROSES KNOWLEDGE MANAGEMENT
}

\author{
Sartika Kurniali \\ Jurusan Sistem Informasi, Fakultas Ilmu Komputer, Binus University \\ Jl. KH. Syahdan No. 9 Kemanggisan Palmerah, Jakarta Barat 11480 \\ Telp. (021) 5345830 Fax. (021) 5300244 \\ sartikakurniali@binus.edu
}

\begin{abstract}
Knowledge management application on the internet keeps growing. It happens because the Internet offers new opportunities to use the knowledge assets, defines and spreads type of new knowledge assets, even to outside the organization. On the internet, appear social media that enable internet-based knowledge sharing system. As we know social media is not something new and has undergone many changes that allow for more interactive interaction and much greater number of users now. The research results showes that knowledge management and social media have nearly similar components. This allows the role of social media on the knowledge management application, such as collaboration tools coming with a clear business purpose.
\end{abstract}

Keywords: knowledge management, social media, internet

\begin{abstract}
ABSTRAK
Penerapan knowledge management di internet semakin bertambah. Hal ini karena internet menawarkan kesempatan-kesempatan baru untuk menggunakan aset pengetahuan, mendefinisikan tipe aset pengetahuan baru, dan menyebarkannya bahkan sampai di luar organisasi. Di internet kini muncul media sosial yang dapat berfungsi sebagai sistem berbagi pengetahuan berbasis internet. Media sosial sendiri bukan hal yang baru dan kini telah banyak mengalami perubahan sehingga memungkinkan adanya interaksi yang jauh lebih interaktif dan jumlah pengguna yang jauh lebih besar. Hasil penelitian menunjukkan knowledge management dan media sosial memiliki komponen yang hampir sama. Hal ini memungkinkan peran media sosial pada penerapan knowledge management, seperti sebagai alat bantu kolaborasi yang disertai tujuan bisnis yang jelas.
\end{abstract}

Kata kunci: knowledge management, media sosial, internet 


\section{PENDAHULUAN}

Knowledge management walaupun merupakan disiplin ilmu yang cukup muda telah melewati beberapa tahapan. Mulai dari mengenali bahwa tacit knowledge memiliki nilai unik untuk organisasi sampai sistem untuk mengelola aset pengetahuan, dan sekarang sampai ke teknologi informasi untuk instalasi sistem knowledge management. Mulai dari yang sederhana hingga yang kompleks.

Di sini akan difokuskan tren knowledge management yang berhubungan dengan intenet. Penerapan knowledge management yang tradisional kini berubah karena munculnya metode-metode yang memungkinkan menggunakan aset pengetahuan, mendefinisikan tipe aset pengetahuan baru, dan menyebarkannya. Internet juga telah menambah alat bantu yang tersedia untuk menerapkan proses knowledge management.

Lalu jika dilihat dari gambaran yang lebih besar dari sekedar sebuah organisasi adanya knowledge management berbasis internet memungkinkan apa yang membuat sebuah aset pengetahuan tidak hanya dari dalam organisasi, tetapi juga dengan kolaborator lain yang juga bertukar pengetahuan atau informasi dengan organisasi.

\section{Studi Pustaka}

\section{Knowledge Management}

Grup Gartner mendefinisikan knowledge management sebagai sebuah ilmu yang mempromosikan pendekatan terintegrasi untuk mengidentifikasikan, mengkategorikan, mengambil kembali, dan berbagi aset informasi suatu organisasi. Proses bermulai pada menangkap pengetahuan, berlanjut ke bagaimana membuat struktur pengetahuan yang baik sehingga lebih mudah tersedia, membagikan pengetahuan kepada orang lain, dan menciptakan pengetahuan baru (Gambar 1).

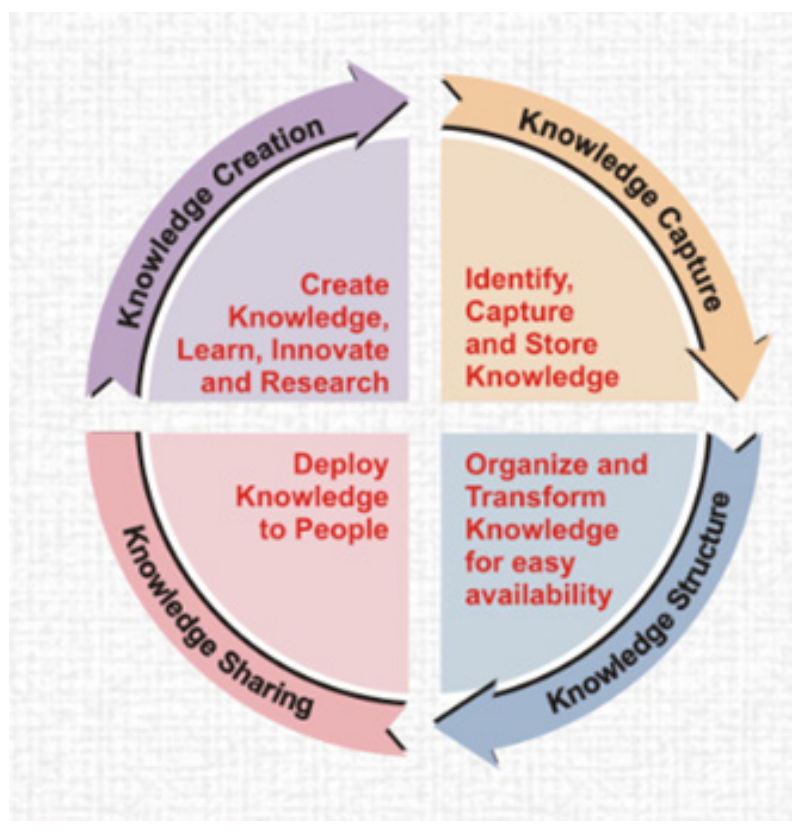

Gambar 1. Proses knowledge management. 
Perbedaan Tacit knowledge dan Explicit knowledge lah yang memulai minat akan knowledge management muncul (Polanyi, 1967). Pada dasarnya tacit knowledge bersifat personal, dikembangkan melalui pengalaman yang sulit untuk diformulasikan dan dikomunikasikan (Carrillo et al., 2004). Berdasarkan pengertiannya, tacit knowledge dikategorikan sebagai personal knowledge management atau dengan kata lain pengetahuan yang diperoleh dari individu (perorangan). Menurut Bahm (1995, p. 199) penelitian pada sifat dasar pengetahuan seketika mempertemukan perbedaan antara knower dan known, atau seringkali diartikan dalam istilah subject dan object, atau ingredient subjective dan objective dalam pengalaman.

Sedangkan explicit knowledge bersifat formal dan sistematis yang mudah untuk dikomunikasikan dan dibagi (Carrillo et al., 2004). Penerapan explicit knowledge ini lebih mudah karena pengetahuan yang diperoleh dalam bentuk tulisan atau pernyataan yang didokumentasikan, sehingga setiap karyawan dapat mempelajarinya secara independent.

Tiga komponen penting pun terdapat pada konsep knowledge management (Gambar 2), yaitu kepentingan untuk memfasilitasi isu orang, proses, dan teknologi.

\section{Knowledge Components}

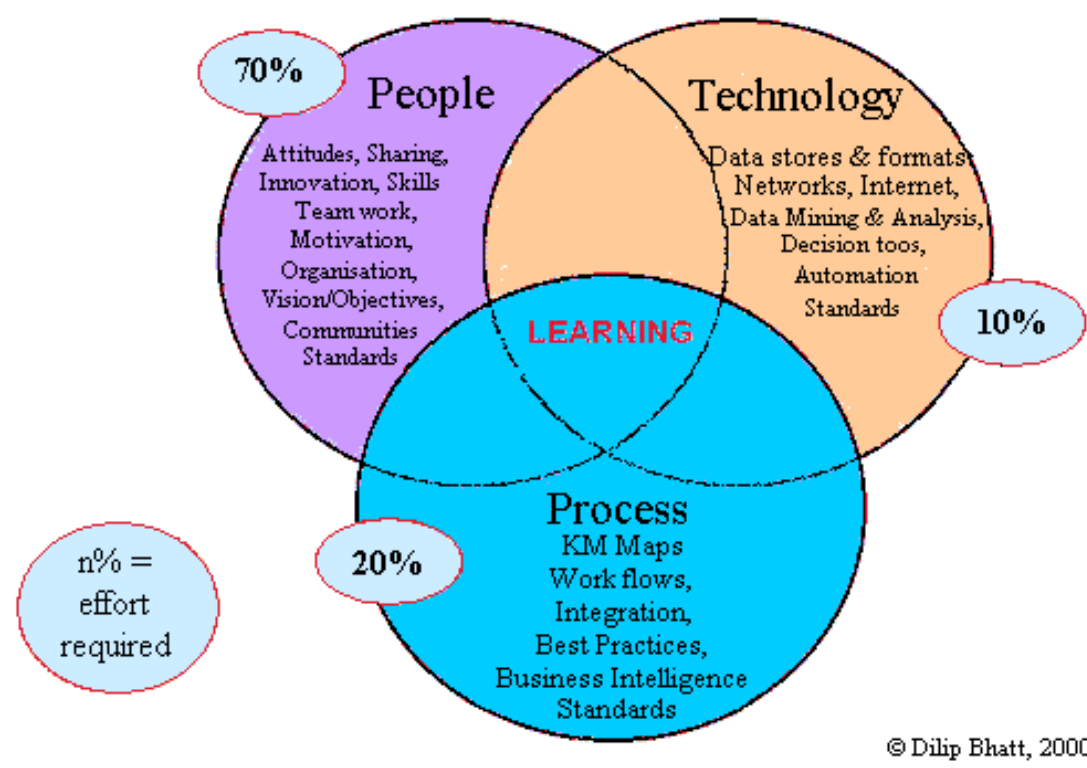

Gambar 2. Komponen knowledge management dan Sub-Elemennya. Sumber: Situs Eknowledge Center

Pada umumnya implementasi strategis knowledge management akan mempengaruhi ketiga komponen pada tingkat tertentu. Oleh karenanya, pertimbangan yang hati-hati harus dilakukan untuk mengantisipasi implikasi yang akan terjadi. Gagalnya implementasi biasanya terjadi karena organisasi memandang knowledge management sebagai implementasi teknikal saja. Tidak berarti bahwa teknologi adalah komponen yang paling tidak penting. Intinya adalah sebuah komponen penting.

Namun, teknologi merupakan komponen termudah dan tercepat untuk diimplementasikan. Sementara langkah untuk menghubungkan knowledge management dengan budaya dan isu orang, pada umumnya akan memakan waktu yang lebih lama dan menghabiskan sumber daya. Keuntungan sesungguhnya knowledge management hanya akan bisa diwujudkan apabila isu yang berhubungan dengan orang diidentifikasi dan dipecahkan. Pada implementasinya pun tetap dapat dibagi-bagi 
menjadi bagian-bagian yang lebih kecil untuk mendapatkan tujuan strategis. Seperti memulai kecil, tetapi berpikir besar (Bhatt, 2000).

\section{Internet}

Adanya peningkatan jumlah kompetitor dan persaingan yang lebih sengit akan dijumpai oleh banyak perusahaan dengan adanya internet. Hal ini disebabkan karena internet menurunkan tingkat entry barrier sehingga memudahkan pesaing baru masuk ke pasar (Porter, 2001).

Selama beberapa tahun belakangan ini pun internet telah memberikan pengaruh penting pada penerapan knowledge management secara tradisional. Instalasi knowledge management berbasiskan web memungkinkan koleksi dan dispersi pengetahuan dari organisasi (Matson, Patiah, dan Shavers 2003).

Sistem seperti ini telah memungkinkan data yang tersimpan bisa diakses di seluruh dunia, fasilitas pencarian, penggunaan peringkat, kegunaan peringkat, dan lainnya. Sistem ini juga dapat digunakan untuk mengembangkan are pengetahuan tertentu. Kebanyakkan aplikasi yang digunakan tidak baru. Konsep dasar dan aplikasi ini telah ada sebelumnya dan telah mengalami perbaikan selama beberapa tahun terakhir ini. Sebelumnya aplikasi ini lebih banyak berurusan dengan explicit knowledge atau mengkatalogkan tacit knowledge. Perbaikan telah membuat aplikasi lebih banyak berurusan dengan tacit knowledge. Dengan berkembangnya pertumbuhan kolaborasi alat bantu yang ada cukup mengejutkan karena mekanismenya sekarang diterapkan pada knowledge management (Vara, 2006).

Mulai dari Wiki sampai dengan website jaringan sosial seperti MySpace, dari file audio atau video sampai ke blog internal dan halaman web yang memudahkan pengguna berbagi persepsi dan perspektif. Alat-alat bantu ini memungkinkan membuat dan berbagi tacit knowledge yang lebih personal. Organisasi yang mengetahui cara melakukan hal-hal ini dapat meningkatkan kemampuan knowledge management yang diterapkannya.

Peningkatan penggunaan aplikasi seperti ini juga didukung oleh semakin baiknya infrastruktur internet di seluruh dunia. Adanya proses yang memerlukan kecepatan yang cepat, penyimpan data yang besar, dan proses yang rumit semakin mudah dilakukan lewat internet.

Berikut ini adalah rangkuman isu yang mungkin timbul di masa depan pada knowledge management system (KMS) berbasis internet (Jennex, 2008):

(1) Pembatasan bandwidth - memperbaiki transmisi dan metode untuk memungkinkan banyaknya jumlah pengguna untuk menerima pengetahuan dari KMS;

(2) Mengorganisir pengetahuan - menciptakan standar ontologi dan taxonomi untuk memungkinkan struktur pengetahuan standar;

(3) Penuhnya web dengan konten - memperbaiki pengetahuan yang akan diambil sehingga konten yang tidak berguna bagi pengguna bisa ditangkap;

(4) Memaintain dan integritas data - memastikan maintenance web terbaharui dan pengetahuan yang akurat bagi pengguna;

(5) Masalah keamanan - menciptakan sistem aman yang memungkinkan akses remote, tetapi tetap menjaga pengguna yang tidak berhak tetap di luar;

(6) Sistem yang tidak kompatibel - memperbaiki kompabilitas antar platform untuk memperbaiki integrasi sistem dan akses

\section{Media Sosial}

Dari sudut pandang bisnis, inti dari media sosial adalah tentang memungkinkan pembicaraan. Media sosial juga tentang cara pembicaraan ini bisa dihasilkan, dipromosikan, dan dijadikan pendapatan (Safko, 2009). Media sosial adalah tempat, alat bantu, layanan yang memungkinkan 
individu untuk mengekspresikan diri mereka untuk bertemu dan berbagi dengan rekan lainnya melalui teknologi internet. Media sosial terbagi menjadi beberapa kategori (Gambar 3) (Cavazza, 2008), yaitu:

(1) Alat bantu publikasi menggunakan blog (Typepad, Blogger), wiki (Wikipedia, Wikia, Wetpaint) dan portal citizen journalism (Digg, Newsvine);

(2) Alat bantu berbagi untuk video (YouTube), gambar (Flickr), link (del.icio.us, Ma.gnolia), musik (Last.fm, iLike), slide presentasi (Slideshare), review produk (Crowdstorm, Stylehive) atau umpan balik produk (Feedback 2.0, GetSatisfaction);

(3) Alat bantu diskusi seperti forum (PHPbb, vBulletin, Phorum), forum video (Seesmic), instant messaging (Yahoo! Messenger, Windows Live Messenger, Meebo) dan VoIP (Skype, Google Talk);

(4) Jaringan sosial (Facebook, MySpace, Bebo, Hi5, Orkut), jaringan sosial spesifik (LinkedIn, Boompa), dan alat bantu untuk menciptakan jaringan sosial (Ning);

(5) Alat bantu mikroblogging (Twitter, Pownce, Jaiku, Plurk, Adocu) dan layanan serupa (twitxr, tweetpeek);

(6) Alat bantu agregasi sosial seperti lifestream (FriendFeed, Socializr, Socialthing!, lifestrea.ms, Profilactic);

(7) Platform untuk hosting (Justin.tv, BlogTV, Yahoo! Live, UStream) dan ada layanan serupa untuk mobile (Qik, Flixwagon, Kyte, LiveCastr);

(8) Dunia virtual (Second Life, Entropia Universe, There), 3D chats (Habbo, IMVU) dan dunia virtual khusus remaja (Stardoll, Club Penguin);

(9) Platform game sosial (ImInLikeWithYou, Doof), portal game casual (Pogo, Cafe, Kongregate) dan jaringan sosial yang dimungkinkan dengan game (Three Rings, SGN);

(10) MMO, massively multiplayer online (Neopets, Gaia Online, Kart Rider, Drift City, Maple Story) dan MMORPG, Massively multiplayer online role-playing game (World of Warcraft, Age of Conan).

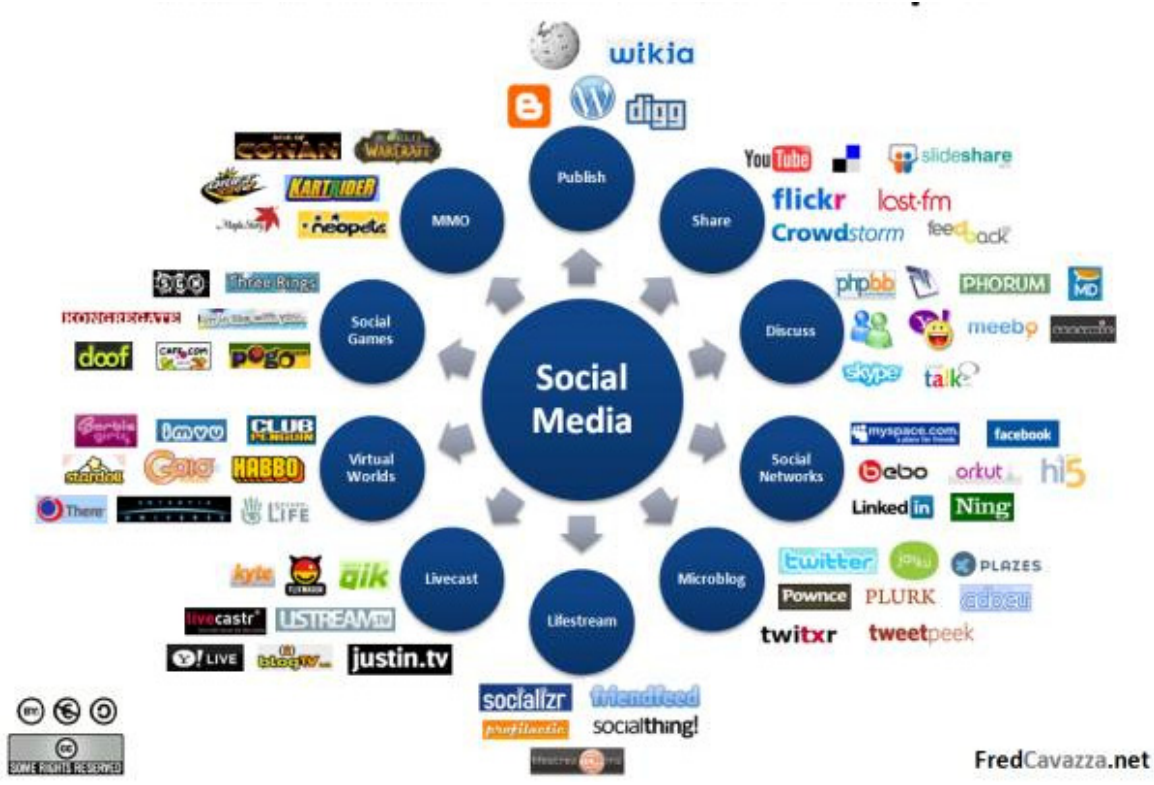

Gambar 3. Pembagian kategori media sosial.

Tampak bahwa banyak dari media sosial ini telah menjadi layanan internet besar yang melayani pengguna di seluruh dunia. Baik yang menyediakan fasilitasnya dengan gratis ataupun yang berbayar. 
Sedangkan, para peneliti di Forrester, menggunakan istilah lain yang kurang populer untuk menggambarkannya, yaitu groundswell. Sebuah tren sosial ketika orang menggunakan teknologi untuk mendapatkan hal-hal yang mereka perlukan dari satu sama lain, daripada menggunakan institusi tradisional, seperti perusahaan $(\mathrm{Li}, 2008)$. Groundswell terjadi karena adanya pertemuan tiga kekuatan, yaitu orang, teknologi, dan ekonomi. Orang selalu bergantung sama lain dan mendapatkan kekuatan dari orang yang lain. Orang juga selalu bertentangan dengan kekuatan institusional., seperti pada organisasi buruh dan revolusi politik. Dua kekuatan ini tidak seimbang, tetapi telah berbalik karena kekuatan dan penyebaran teknologi sosial.

Teknologi, telah merubah semua hal tentang bagaimana orang melakukan interaksi sosial. Hal ini penting karena aplikasi yang bisa menghubungkan orang kini bisa mengasumsikan dirinya bahwa akan ada sejumlah orang di sana untuk dihubungkan.

Hal ini telah membuat munculnya aplikasi yang jauh lebih interaktif karena semakin baiknya infrastuktur yang ada dan karena mereka menghubungkan orang bahkan secara langsung pada pada waktu yang bersamaan. Berdampingan dengan keinginan orang untuk berhubung dan teknologi baru adalah kekuatan ketiga, ekonomi online, yaitu di internet, traffic sama artinya dengan uang. Ketiga tren ini, keinginan orang untuk terhubung, teknologi baru yang interaktif, dan ekonomi online telah menciptakan era baru. Tidak hanya ada di sini sekarang, tetapi juga berevolusi dengan sangat cepat, menciptakan tantangan hebat bagi strategi organisasi.

\section{Knowledge Management dan Media Sosial di Internet}

Teknologi merupakan salah satu elemen pokok yang terdapat pada knowledge management, dikenal sebagai media yang mempermudah penyebaran explicit knowledge. Internet sendiri menyediakan fitur agar kebutuhan untuk mengakses knowledge management dan melakukan kolaborasi, komunikasi serta sharing knowledge management secara dapat dilakukan dengan lebih mudah, cepat, dan pada waktu yang bersamaan (Kosasih, 2007).

Hal ini lah yang ditawarkan pula oleh media sosial. Berikut ini adalah pemetaan kegiatan pada knowledge management yang dapat dilakukan juga pada masing-masing kategori media sosial (Gambar 4) (Jiang, 2006):

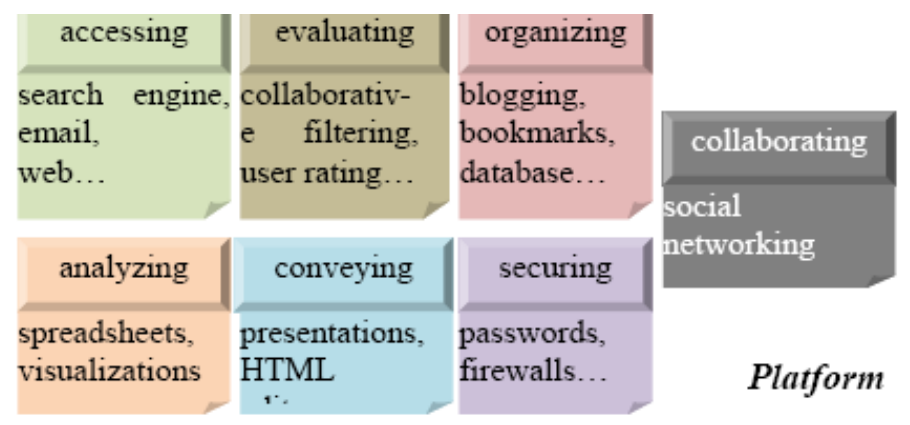

Gambar 4. Pemetaan kegiatan pada kategori media sosial.

\section{Karakteristik}

Karakterisktik dari penyebaran pengetahuan secara teknologi yang pertama adalah asynchronous atau tidak berurutan untuk jenis seperti forum dan dokumen tertulis. Keuntungan utama dari media ini adalah individu tidak hanya bebas berada di lokasi yang sama, tetapi juga dari menjadi tersedia pada saat yang sama. Pengirim bisa mengirmkan pengetahuan yang langsung ditangkap untuk 
penyimpanan dan penggunaan kembali, dan penerima bisa mengakses pengetahuan ketika sangat memerlukannya. Kerugiannya terkait karena tidaknya adanya klarifikasi langsung tentang pengetahuan tersebut, terutama ketika pada saat pertama kali disimpan. Yang kedua jika dilakukan secara synchronous untuk jenis seperti instant messaging dan chat room. Media komunikasi ini membebaskan individu untuk berada di tempat yang sama mereka membagikan pengetahuan dan sangat berguna untuk organisasi yang tersebat. Kerugiannya adalah dapat menghasilkan salah paham karena gagal memberikan nuansa komunikasi yang lengkap. Sebagai tambahan, tidak semuanya pada kategori ini memberikan fasilitas perekaman dan pembagian pengetahuan pada saat itu juga.

Diberikan pilihan karakteristik ini, maka diperlukan beberapa kriteria untuk memilih media yang paling tepat untuk jeni-jenis pengetahuan yang termasuk tacit-explicit. Kekayaan media dan kehadiran sosial adalah dua kriteria yang dapat digunakan dalam memilih mana yang tepat (Dalkir, 2009).

\section{Tujuan}

Perusahaan yang tampak paling sukses menggunakan media sosial sebagai alat bantu kolaborasi adalah yang menggunakannya baik sebagai murni alat bantu sosial atau sebagai peralatan infrastruktur. Sebagai contoh pada satu organisasi jasa profesional mereka membuat Facebook internal, tetapi tujuan utamanya adalah membantu karyawan untuk mendapatkan teman di tempat kerja. Sedangkan di sebuah perusahaan kontraktor mereka menggunakan aplikasi dengan gaya Facebook untuk meningkatan keahlian mereka.

Penggunaan kolaborasi ini juga bisa difokuskan dengan tujuan bisnis yang jelas. Jadi, ada dua pilihan, yaitu kolaborasi terfokus dengan tujuan bisnis yang jelas atau alat bantu kolaborasi untuk tujuan sosial atau infrastruktural. Organisasi akan mendapatkan masalah ketika mereka terjebak antara dua pilihan ini. Mereka hanya membuat beberapa alat bantu kolaborasi, entah itu media sosial seperti wiki, jaringan sosial, dan membiarkannya begitu saja. Berharap semua pihak akan berkolaborasi menyumbangkan pengetahuannya. Tanpa menegaskan suatu tujuan kolaborasi atau manfaat bisnis, tetapi mengharapkan nilai bisnis. Adanya teknologi tidak serta merta membuat terjadinya kolaborasi dan memberikan ROI (Return on Investment).

Perbedaan jelas tentang kolaborasi untuk tujuan bisnis adalah merupakan sebuah pekerjaan. Penggunaannya perlu diatur seperti proyek lainnya atau sebuah proses. Memiliki sebuah teknologi untuk memfasilitasi kolaborasi membuatnya lebih mudah, tetapi ini merupakan pekerjaan. Seperti pada contoh di atas, jaringan sosial untuk tujuan sosial memang menyenangkan. Jika digunakan sebagai alat bantu kolaborasi, maka akan menjadi sedikit menyenangkan (jika semua orang bisa ikut membagikan informasi personalnya, seperti anak mereka, hobi mereka, dan lainnya), tetapi media sosial ditujukan untuk membuat kehidupan di organisasi lebih efisien. Ketika tidak ada pengertian yang jelas tentang apa yang merupakan pekerjaan dan apa yang menyenangkan, pada saat itulah organisasi akan menemui kesulitan dengan media sosial (Davenport, 2008).

\section{PENUTUP}

Kesimpulan yang didapatkan adalah internet merupakan infrastruktur knowledge management yang efektif. Salah satu penerapannya dengan menggunakan media sosial juga dapat digunakan sebagai alat bantu berkolaborasi dengan semua pihak yang berhubungan dengan organisasi. Tidak hanya secara internal, seperti pada konsep knowledge management tradisional. Hal ini didukung juga oleh hampir samanya komponen yang membentuk knowledge management dan sosial media. Persamaan yang ada adalah pada komponen orang dan teknologi. 
Untuk menggunakan media sosial organisasi juga tidak bearti harus membangunnya semua sendiri. Karena telah ada media sosial di internet yang menyediakan layanannya baik dengan gratis ataupun dengan berbayar. Juga beberapa berupa paket program open source yang bisa digunakan dan diseting kembali untuk penggunaan internal.

Namun, untuk media sosial bisa menjalankan fungsinya sebagai alat bantu kolaborasi juga diperlukan tujuan bisnis yang jelas. Tujuan ini diperlukan agar organisasi tidak terjebak antara penggunaan media sosial yang murni untuk sosial dan sebagai peralatan infrastruktur. Dengan begini, maka penggunaan media sosial dapat menyumbangkan nilai tambah bisnis dalam bentuk dukungannya terhadap proses knowledge management.

\section{DAFTAR PUSTAKA}

Bhatt, Dilip. (2000). Excellence Model and Knowledge Management Implications. Diakses dari (http://www.eknowledge managementcenter.com/articles/1010/1010.htm.

Bhatt, Dilip. (2000). Knowledge Components. Diakses dari http://www.eknowledgecenter.com/articles/1010/1010.htm

Carrillo, P., Robinson, H., Al-Ghassani, A., Anumba, C. (2004). Knowledge Management in UK construction: Strategies, Resources and Barriers. Project Management Journal. 35 (1), 46.

Cavazza, Fred. (2008). Social Media Landscape. Diakses (http://www.fredcavazza.net/2008/06/09/social-media-landscape/.

Davenport, Tom. (2008). The Muddle in the Collaboration Middle. Diakses dari (http://blogs.harvardbusiness.org/davenport/2008/04/the muddle_in the collaboratio.html.

Jennex, Murray E. (2008). Knowledge Management Concepts, Methodologies, Tools and Applications. Hershey: IGI Global.

Jiang, Tingting and Daqing, He. (2006). Redefining Social Network Services: A Solution to Personal Information and Knowledge Management Proceeding.

Kosasih, Natalia dan Sri Budiani. (2007). Pengaruh Knowledge Management Terhadap Kinerja Karyawan: Studi Kasus Departemen Front Office Surabaya Plaza Hotel. Jurnal Manajemen Perhotelan, 3 (02), 80-88.

Li, Charlene and Josh Bernoff. (2008). Groundswell: Winning in a World Transformed by Social Technologies. Massachusetts: Harvard Business Press.

Polanyi, M. (1967). The Tacit Dimension. New York: Anchor Day Books.

Porter, Michael E. (2001). Strategy and the Internet. Harvard Business Review, 79 (3), 63-78.

Safko, Lon and Brake, David K. (2009). The Social Media Bible: Tactics, Tools, and Strategies for Business Success. New Jersey: John Wiley \& Sons. 